\title{
Miranda
}

Revue pluridisciplinaire du monde anglophone /

Multidisciplinary peer-reviewed journal on the English-

speaking world

$12 \mid 2016$

Mapping gender. Old images ; new figures

\section{Geoffrey Philp and the Reggae Aesthetics}

\section{Eric Doumerc}

\section{OpenEdition}

\section{Journals}

Electronic version

URL: http://journals.openedition.org/miranda/7825

DOI: $10.4000 /$ miranda.7825

ISSN: $2108-6559$

\section{Publisher}

Université Toulouse - Jean Jaurès

\section{Electronic reference}

Eric Doumerc, "Geoffrey Philp and the Reggae Aesthetics", Miranda [Online], 12 | 2016, Online since 24 February 2016, connection on 16 February 2021. URL: http://journals.openedition.org/miranda/7825 DOI: https://doi.org/10.4000/miranda.7825

\section{This text was automatically generated on 16 February 2021.}

\section{c) (7) $९$}

Miranda is licensed under a Creative Commons Attribution-NonCommercial-NoDerivatives 4.0 International License. 


\title{
Geoffrey Philp and the Reggae Aesthetics
}

\author{
Eric Doumerc
}

In his poetry anthology entitled Wheel and Come Again: An Anthology of Reggae Poetry, Kwame Dawes gathered a number of poems which were based on

a reggae aesthetic-an aesthetic that one can discern in the dub poetry of Linton Kwesi Johnson and in the sonnets of Geoffrey Philp. Sometimes these poems do not look anything like a reggae song, but at their core and in their attitudes they represent a dialogue with reggae (Dawes 1998, 22).

In the introduction, Dawes established a distinction between dub poetry and reggae poetry, and insisted that reggae poetry was not poetry based on reggae rhythms or poetry that necessitated a reggae accompaniment to make its point. He insisted that the poetry contained in his anthology had been "shaped and given character by reggae music" (22), but was very different from traditional dub poetry, a "poetic expression that relies primarily on performance and more often than not on a band playing behind the words" (22). He made the point that dub poetry had somewhat limited the scope of what writers could do with reggae music and seemed to find dub poetry too limiting as an art form.

In his book entitled Natural Mysticism: Towards a New Reggae Aesthetic, Dawes identified a new aesthetics which has underpinned the work of numerous Caribbean authors since the 1960s and which has drawn heavily on Jamaican popular music. Dawes laid the emphasis on reggae's appeal to his own generation growing up in the 1970 s and finding it hard to relate to the work of writers associated with the "nationalist period" (the 1930s and 1940s) and claimed that reggae constituted for this younger generation an alternative to literature and the arts since Jamaican popular music dealt with certain burning issues back then. ${ }^{1}$ It did so in the language of the people, using an aesthetics the working classes could easily and readily identify with because it was derived from reggae music. This aesthetics was based on "the emergence of Jamaican Nation Language as the language of artistic expression" (Dawes 1999, 97), the use of "Rasta 
talk" (98) and a "focus on history and on race" derived from the influence of Rastafarianism (99).

Geoffrey Philp was one of the poets included in Dawes' anthology of reggae poetry, and his poems seem to constitute a creative engagement with reggae music and with its culture. His first four collections of poetry (Exodus and Other Poems, 1990; Florida Bound, 1995; Hurricane Center, 1998; and Xango Music, 2001) signalled the arrival of a major new poetic talent walking in the footsteps of Derek Walcott, Mervyn Morris, Dennis Scott and Kamau Brathwaite among others. His most recent collection, Dub Wise, came out in 2010. Like the poems of Mervyn Morris, Tony Mc Neill, and Dennis Scott, three Jamaican poets who were featured in Dawes' anthology, Philp's poetry cannot be referred to as "dub poetry" in the sense of reggae-driven poetry or poetry based on performance or on reggae rhythms. On the other hand, his poetry seems to contain some features of the reggae aesthetics identified by Dawes in his theoretical writings.

Reggae makes its presence felt in Philp's poetry through the concept of "versioning". This concept is used in various ways by the poet to rewrite and comment on some important poems which are part of the canon of Caribbean literature. This concept could at times be applied literally to Philp's poetry as some of his poems are rewritings of well-known pieces. Philp's method here recalls the concept of intertextuality as well as Gérard Genette's theory of transtextuality. In other poems, Philp's technique subtly switches from rewriting poems to disseminating echoes from other poems in his own poetry. Lastly, in many other poems, Philp seems to use the concept of versioning in a more Jamaican way which refers to the Jamaican music industry.

\section{Intertextuality}

Some of Philp's poems can be considered as new versions of well-known Caribbean poems in the conventional sense of the word and can be seen as rewritings of these pieces. These poems can be said to be characterised by a degree of intertextuality with other well-known Caribbean poems. Intertextuality is "a term coined by Julia Kristeva in 1966 to denote the interdependence of any one literary text with all those that have gone before it" (Cuddon 454). As David Lodge wrote, "Some theorists believe that intertextuality is the very condition of literature, that all texts are woven from the tissues of other texts, whether their authors know it or not" (Lodge 98-9). In Palimpsestes, Gérard Genette identified five types of transtextuality: intertextuality, paratextuality, metatextuality, architextuality, and hypertextuality (Escola). Many poems by Geoffrey Philp can be said to be "woven from the tissues" of earlier Caribbean classics and to be characterised by a certain degree of intertextuality. According to Genette, intertextuality includes the presence of a text in another text (Escola). For instance, Philp's early poem "Dance Hall" $(1995,11-2)$ is a retelling of Derek Walcott's "Tales of the Islands; Chapter VI" (1986, 24-5). Walcott's piece used the Petrarchan sonnet form with its division into an octave followed by a sestet, and was set in Trinidad during a "fete" (24):

Poopa, da' was a fête! I mean it had

Free rum free whisky and some fellars beating

And everywhere you turn was people eating

And don't name me but I think

They catch his wife with two tests up the beach (24-5) 
7 In this piece, Walcott used Trinidadian Creole, with its French-influenced vocabulary ("fête") and syntax ("it had") to create a specific mood. Various social types like the middle-class intellectual freshly returned from England whose wife was caught "up the beach" with two "tests" ("men") were satirised by Walcott, and the poem ended on a dark note with the evocation of some Amerindian ritual involving a human sacrifice before the first African slaves arrived in the West Indies. In Walcott's piece there was a marked contrast between the joyful and careless atmosphere at the "fete", and the troubled history of the island.

Philp's take on Walcott's sonnet is set in Jamaica at a sound system dance and can be seen as a reggae or "reggaefied" version of Walcott's Trinidadian tale:

Man, mek me [let me] tell yu, dat was a fete.

Riddim was wile, an de dawta dem a grine,

De idren dema smoke de sweetes lamb's bret

Straight from St. Ann's, de bes colly we cud fine $(1995,11)$.

Right from the start, a specifically Jamaican vocabulary is resorted to, with words from the reggae subculture ("riddim", i.e. "rhythm") and from the Rastafarian cultural sphere ("idren"2, "dawta"3). The Rastafarian word for marijuana ("colly", sometimes "colly weed" (Pollard 32)) is also used to create a particular atmosphere. The voice we hear in this poem is a Creole, working-class or lower-class one, telling one of his friends about a violent incident which happened at a sound system dance. The first part of the sonnet, the octave, continues in this mode and sets the stage for the tragedy which is related in the second part (the sestet). The incident related in the same Creole voice concerns a drunken patron of the sound system dance ("a fool-fool rumhead", i.e. "a stupid drunkard") who "chucked a yute", that is killed a young man. The tone of the poem changes in the sestet and the poet seems to imply that human life is very cheap in Jamaica when the murdered youth's girlfriend searches his body, retrieves a gold ring, and then "shub him dung a dutty" ("threw him down on the ground"). The dance was then supposed to end, but some powerful, bass-driven "oldies" were put on by the selector, and the dance in fact was allowed to go on. The last lines of the poem are quite ambiguous, hinting at the ruthlessness of the sound system patrons, who quickly forgot about the poor "yute's" death, but on the other hand, the poem could also be read as reflecting lower-class Jamaicans' resilience in the face of violence and death, and the role played by reggae music in their day-to-day struggle to survive.

Another example of Philp's versioning of famous classics of Caribbean poetry would be his rewriting of Mervyn Morris's "I Am the Man" in his poem "I Man" (Philp 1998, 35). Morris's "I Am the Man" uses anaphora to give a voice to the voiceless and to draw the reader's attention to social deprivation in Jamaica. The poem is made up of four stanzas which all begin with the anaphora "I am the man" and end with a shorter line, which is addressed to the reader or to "society":

I am the man that build his house on shit

I am the man that watch you bulldoze it

I am the man of no fixed address

Follow me now (Mordecai 173)

11 Morris's poem ends with the line "Study me now", which can be interpreted both as an encouragement to pay more attention to what the poor have to say, and as a Creole phrase meaning "Watch me closely". The poem is a product of the tensions that characterised Jamaican society in the 1970s. 

its form and in its content. Indeed Philp's poem is composed of seven couplets which deal with the same theme of social deprivation as the one in Morris's poem, but in Philp's piece the reader from the middle and upper classes is addressed more often as "yu". The opening and closing couplets introduce the main "I/yu" dichotomy:

$i$ am the man yu tun way from the door

i am the man who face white wid yu spit,

i am the man who sleep in the cradle of the banyan

i am the man yu wudn call yu bredren $(1998,35)$

Philp's poem can be seen as a Rasta-influenced rewriting of the earlier piece, as is suggested by the title, "I Man", which is a well-known I-word coined by the Rastafarians, and by the resort to a Rastafarian vocabulary ("bredren"4). Indeed, as pointed out by Velma Pollard, the Rastafarians refashioned the English language to tailor it to their worldview and came up with a number of "I-words". In these words, "I" is not only a more assertive pronoun which replaces the "me" used in Jamaican Creole, but also a "prefix to some nouns and a replacement for the initial sound in any number of words" (Pollard 7). In Philp's poem, the use of the word "I-man" could be seen as a reference to the persona's humanity ("I-man" or "human") which is being denied to him by society's indifference to his plight.

\section{Intertextual echoes}

Echoes from Bob Marley's songs naturally abound in Philp's reggae-influenced poetry. For instance, Marley's "Rebel Music (Three O'Clock Roadblock)" was the obvious inspiration for two poems by Philp: "8 o'clock road block or prelude to a riot" (1998, 33), a piece dedicated to Tony McNeill, and "One Song" (Dawes 1998, 157). Bob Marley "Rebel Music (Three o'clock Roadblock)" dealt with the twin issues of police harassment and the victimisation of Rastafarians who were often stopped and searched by the police. In Marley's song, the police ("Mr Cop") were pitted against the Rastas, but also against young people who felt that "society" stopped them from living their life the way they wanted to. Marley's song was released in 1973 and was banned from Jamaican radio on account of its incendiary lyrics. In Philp's "8 o'clock road block or prelude to a riot", a black man stops traffic by climbing on top of a "highway railing" and then is brought down by a police officer who uses a rope to force him to come down and in the process strips him naked. The black man falls to the ground and becomes a Christ-like figure. Philp's poem seems to take up the thread of the narrative where Marley left off and extends his story beyond the point of the confrontation between the police officer and the black man. At the end of the poem, the black man whirs "through the air like an electron freed of its orbit" and sends "radical isotopes", causing the city to "blck out". Philp's Christ-like figure in this poem recalls some of Mc Neill's pieces like "When I fell in the valley" (Mordecai 143) or "Notes on a September Day" (Mordecai 140) in which images of falling and downward movements seem to predominate. A cluster of images is thus created around Mc Neill's and Marley's pieces. In "One Song", a poem about the power of reggae, words from Marley's songs are quoted and recur at strategic places in the poem, thus playing the part of a few snatches from a song echoing in a dub mix: 
when dis ya bass-line drop

is like rebel music bus inna mi brain (Dawes 1998, 157) allusions to well-known Caribbean poems. These allusions might be seen as echoes from the Caribbean literary canon or tradition. For instance, Philp's echoing technique is particularly efficient in "Fort Augusta", a meditation on the colonial legacy which is loosely based on Derek Walcott's "Ruins of a Great House". In Philp's piece, the persona enters the ruins of an old fort and comes face to face with history, symbolised by the reference to "Morgan, Drake, Hawkins" $(1995,18)$. In Walcott's poem, the persona is torn apart between revenge and forgiveness after going into the grounds of a "great house" which symbolises the days of slavery, until in the end "all in compassion ends". The very first lines of Philp's poem ("Crows flapped from the limbs of acacia") echo Walcott's own "three crows flap for the trees/And settle, creaking the eucalyptus boughs" in "Ruins of A Great House" (Walcott 1986, 19):

Crows flapped from the limbs of acacia.

The fort wall, a rage of stone, broken

by seeds, resisted the sea; fishermen's

nets, sewn seamless as sea-fans, caught

mute harmonies of the polyp (Philp 1995, 18)

The reference to "Morgan, Drake, Hawkins" in Philp's piece echoes Walcott's allusion to the "ancestral murderers" Donne, Drake, Hawkins, and Raleigh in "Ruins of a Great House". Philp's echoing technique also appears in the excerpt quoted above as the line "the mute harmonies of the polyp" brings to mind the reference to the "polyp" in "The Castaway": "If I listen I can hear he polyp build" (Walcott 1986, 58). Likewise, the reference to nothingness or to the void at the end of the poem also recalls the line "Nothing: the rage with which the sandfly's head is filled" in "The Castaway" (Walcott 1986, 57). So Philp's version could be seen as a "dub version" of Walcott's "Ruins of a Great House", but with echoes from other pieces. This recalls the dub aesthetics which relies on fragments from a well-known song to arouse the listener's curiosity. The "women's laughter" which "sank in the water" recalls the young girls in "Ruins of a Great House" whose remains had been "mixed with candle dust" (Walcott 1986, 19) and whose life had been very short ("moths"):

Past the lattice of bamboo, I climbed

the fort by evening, its hall cleared

of women's laughter, bright as coins

that sank in the water (Philp 1995, 18)

These literary echoes invite the reader to establish connections between various poems by Derek Walcott and to read these poems in relation to Philp's own poetry. As a consequence, the reader becomes aware of the fact that a tradition is being forged 
through intertextuality. In an interview he granted me in July 2012, Geoffrey Philp said that

you don't have a tradition in literature until you have intertextuality. And so it was my intention to create this kind of intertextuality. I think really and truly now we can talk about a Caribbean literature. I think before that, you had a lot of talent, Brathwaite, Walcott, Roach, Martin Carter, and those were the pioneers. You had Brathwaite and Walcott, two different ways of approaching it, and Walcott is clearly saying the craft has to come first. (Doumerc 75) influence on Philp's development as a poet. Indeed, in some of his poems Philp deals with African retentions in the New World, which shows the influence of Kamau Brathwaite's poetry. The major influence was probably Brathwaite's Islands (1969) which formed part of his trilogy The Arrivants subsequently published in 1973. Philp's "Limbo: Version" celebrates the resilience of African culture in the Caribbean and brings to mind Brathwaite's "Negus" as well as John Agard's poems about the "limbo dancer" in his collection Limbo Dancer in Dark Glasses, surviving the ordeal of the Middle Passage to create a new Afro-Caribbean culture in the New World:

Spirit flashes down the spine of twin

crosses that hold my body, yet free

my arms to undulate through time

until I am as small as a spider;

drums pull me under the tide

that has borne so many back to Guinee (Philp 2010,19)

In this excerpt, the limbo dancer appears as the bearer of ancestral culture as he becomes reincarnated as Anansi, the West African spider who appears as a character in so many West Indian folk tales and stories.

Another possible inspiration is the poem entitled "Caliban" by Brathwaite, which establishes a clear connection between the cramped conditions on board the slave ship and the limbo dance, and reinterprets the limbo dance as a form of resistance to slavery:

Limbo

limbo like me

stick is the whip

and the dark deck is slavery (Brathwaite 37)

The survival of African cultural forms in the New World is the main theme of Philp's "Gathering of the Gods: Miami 2010", a modern version of Brathwaite's "Ogun" (Brathwaite 85-6), a poem which deals with the theme of ancestral culture in the Caribbean by focusing on the poet's uncle, a carpenter whose art could be seen as the reincarnation of Ogun, the Yoruba deity, in Barbados. At the end of the piece, the uncle's sculpture finally takes shape as the "emerging woodwork image of his anger" (86) and as modern incarnation of African culture in Barbados.

In "A Gathering of the Gods: Miami 2010", Philp celebrates the reincarnation of the Yoruba deities Ogun, Shango and Olodumare in modern America ${ }^{5}$ :

The six o'clock train, emissary of Ogun,

whistles through West Dixie, the meandering line

that divides Miami, while my daughter

cruises through amber haze and I lisp 
my entreaties to the orishas to keep her safe

from flying metal $(2010,20)$

In this excerpt, the Yoruba deity Ogun, the god of war and metal work, is present through the reference to the "train" and to the "flying metal" of bullets. The word "orisha" refers to deities found in the Yoruba religion which was transplanted to the Caribbean and to Brazil at the time of the slave trade. In Miami, the Yoruba influence is linked with the presence of santeria, a syncretistic cult which mixes Catholicism with the Yoruba religion. The link between Philp's piece and Brathwaite's is but a distant echo and the impact of the poem depends on the reader's familiarity with Brathwaite's poetry. This recalls Gérard Genette's notion of architextuality, or a distant allusion to another text (Escola).

\section{Versioning in a more Jamaican way}

Apart from its obvious similarity with the concept of intertextuality, Philp's versioning can also be said to have a more specifically Jamaican dimension. Other poems by Geoffrey Philp are different versions of well-known classics in a different sense of the word. In such poems, the word "version" appears in the very title of the poem and gives the reader an indication as to the poet's intentions. Paratextuality refers to the link between a text and its paratext, that is its title, subtitle, etc. (Escola). In some poems by Geoffrey Philp, the paratext guides the reader in his reading of the poem through the use of the word "version". In Jamaican English, the word "version" can refer to the practice of recording an instrumental or DJ track on the B side of a Jamaican $45 \mathrm{rpm}$ record, thus producing a new version of the original recording. In the Encyclopedia of Jamaican Heritage, Olive Senior, quoting at times the musicologist Kenneth Bilby, gave the following definition of the term "version":

a second or additional variation on the original, deriving from a practice in the music industry in which the flip side of a record would include an instrumental version or "mix" of the song on the other side. In the 1960s, DJs at dances began to improvise "toasts" or "raps" over these instrumentals, thus giving birth to a poetic and musical style that became known as "Dub" (503).

The person who is usually credited with inventing the practice of versioning is Osbourne Ruddock, also known as King Tubby, a sound engineer who began to remove or fade out the instrumental track to test the quality of the vocals of a particular record. He then continued to cut back and forth between the vocal and instrumental tracks, thus producing an unexpected effect of tension and release (Hebdige 83). These first "mixes" were the first "dub" records and King Tubby tested them at a dance where his sound system was playing, and they met with the crowd's approval. In time, dub became a sub-genre of reggae music and went through a golden age in the 1970s. A dub track normally features the original drum and bass pattern of the original track, but with the vocals removed and then mixed back in, or with a degree of echo and sound reverberation applied to the track. As Dick Hebdige wrote:

On the dub the original tune is still there but it is broken up. The rhythm might be slowed down slightly, a few snatches of song might be thrown in and then distorted with echo. The drums and bass will come right up to the listener and demand to be heard (83). is a Creole, working-class voice and the persona is a lower-class black woman who 
works as a "mule", that is who makes a living by smuggling drugs abroad. The title of the poem refers to a well-known 1971 rock-steady song by Count Prince Miller which is in fact a version of an old country and western tune. So the poem is a version of a song that is itself a version of another song. So ironies multiply as the original "Mule Train" was an American tune recorded by Frankie Laine in 1949, and the situation recounted in Philp's poem concerns a person who smuggles drugs between America and Jamaica. In the poem, the persona is in a queue at some airport and is terrified at the idea that she might be arrested. But in fact the plastic bags she is carrying in her stomach are beginning to give, and she can already feel "de acid bubblin'/up me throat an' unda me tongue" (Philp 2010, 42). In fact she is trapped: even if she "mek it", her health will have been damaged. In "Mule Train: Version", the word "version" is a paratextual distant allusion to another genre, the popular song, and the meaning of the poem will thus be determined by the reader's familiarity with Frankie Laine's song or with Count Prince Miller's version-or with both!

In "Healing in the Balmyard", a Jamaican immigrant in Miami finds some solace in Revivalism, a Jamaican Afro-Christian cult which first appeared in the nineteenth century, at the time of the "Great Revival" (1864-65), and became very popular with the working classes. Prayer meetings were then held in "balmyards". But the title of the poem also echoes a famous reggae song by the Jamaican band Stanley and the Turbines. By alluding to that song in the title of his poem, Philp may have attempted to point out the survival of Jamaican religious practices and the popularity of reggae music in Miami. So the whole poem could be seen as a comment on the diasporic nature of Jamaican music today:

dressed in my gabardine suit, miami heat prickling my neck, filled with the spirit, I'm ready to shout (Philp 2001, 37)

Geoffrey Philp also refers to Jamaican popular music in his poem entitled "Dance Hall: Version", which is a version of the piece studied above. In this reggae-influenced rewriting of his earlier piece, Philp replaced the sonnet form with tercets and used enjambment to telling effect:

you see me dying trial, gun inna the dance:

after you wake up with crosses, gingy fly

round my head, like I was deaf, crosses inna me

bed like ants crawling over my chest, inna the yard

rubbing themselves gains the tamarind, make me want

to fling this bag of bone like it worth a raas? $(1998,29)$

In this passage Philp resorts to enjambment to insist on the persona's predicament: he is a ghetto dweller who lives in squalid conditions, surrounded by small or fruit flies ("gingy fly") and who comes to think of himself as a walking skeleton who is worth nothing. This poem is a version of the earlier one from the point of view of form, and also from the point of view of content. Indeed the earlier poem told a woeful tale of death and violence, but the new version insists on the healing power of reggae music and on its ability to act as a balm for the poor. The persona in the poem is from the lower classes and has to put up with various problems, but in the end the dance hall with its soothing reggae music will help him to get through another day as he will "sip some mannish water, rent-a-tile, clean the cobweb from the corner/of me brain" and "sing in time with gregory isaacs, the cool/ruler on the turntable, yes, yes, yes" 
(Hurricane Center 29). In this poem, the word "version" carries all kinds of associations with reggae culture, as is evidenced by the reference to Gregory Isaacs (1951-2010), a legendary reggae singer who was known as the "Cool Ruler" and who sang romantic ballads. "Mannish water" is "goat-head soup" (Allsopp 370) in Jamaica and "rent-a-tile" (from to rent a tile, that is to remain stationary, as if glued to a tile) refers to a particular type of close-dancing associated with early reggae music. These cultural associations work with the word "version" in the title to make Philp's piece more than a mere retelling of his earlier poem.

Another example of Philp's use of the word "version" in a Jamaican way is the poem "Ode to Brother Joe: Version" $(2010,44)$ which is a reggae or Rasta-influenced version of Tony McNeill's classic "Ode to Brother Joe" (Dawes 1998, 136). Tony Mc Neill was one of the first post-Independence Jamaican poets to deal with the theme of Rastafarianism in his poetry, and to present Rastafarians as important figures in Jamaican society. The main character in his "Ode to Brother Joe" is a Rastafarian who gets arrested by the police for smoking marijuana whereas he was using this herb for religious purposes. Brother Joe is presented as a devout Rastaman who reads the Bible and praises his god. But "the law thinks different" (Dawes 1998, 136) and he is arrested for smoking marijuana and sent to jail. His wife tries to find a lawyer for him, his friends feel sorry for him, but his god "couldn't care less". The poet is broadly sympathetic to Rastafarians but seems to imply that they are fighting a losing battle. The last words of the poem ("But the door is real and remains shut") make it clear that the poet distances himself from the Rastas' optimism and idealism and questions the Rastafarian ethos.

In Geoffrey Philp's "version", Brother Joe was arrested for "crack this time" and is still in jail. His wife is still trying to find a lawyer for him and his "brethren" are still "burning the weed and beating the drums", are still trying to find a new prophet to save the black race, and the whole island. The poem seems to imply that nothing has really changed since the time when McNeill wrote his "ode" and that Rastafarians are still oppressed by Jamaican society and are still relying on the same myths and beliefs. But the conclusion of the poem is significantly different from McNeill's ode as the persona includes himself ("we and him") among the people supporting Brother Joe and waiting for the door to "open":

and we and him watching and waiting

or the door to open-still catching hell $(2010,44)$

Philp's version of McNeill's poem seems to imply a closer identification with Brother Joe and with the Rastafarians' plight, whereas McNeill's stance was that of the detached observer commenting on the Rastafarians' absurd situation. It is a "version" which is deeply influenced by the reggae aesthetics identified by Dawes in his Natural Mysticism, with its reliance on Creole ("still catching hell"), Rasta talk and the themes of race and history. Philp's version is different from a mere "re-writing" of a poem because of the cultural associations implied by the word "version" in the title, and because of the Rasta-influenced ethos which dominates the poems: the persona obviously identifies with the Rastafarians and is sympathetic to their cult.

Thus Geoffrey Philp's poetry seems to fit the definition of "reggae poetry" proposed by Kwame Dawes in Wheel and Come Again, a definition which emphasises the use of Creole, the resort to "dread talk", and a focus on history and race. That definition also sets this type of poetry apart from conventional dub poetry, with its reggae-based rhythms and social themes. But dub remains a potent source of inspiration for Philp and his creative 
use of the concept of versioning sets his poetry in the context of Jamaican popular music and makes it possible for him to replicate in a literary context some of the techniques used by Jamaican sound engineers like echo and sound reverberation. In the process, Philp produces his own "version" of intertextuality in a post-colonial context through a dialogue with reggae music and its "bass culture" (Johnson 57).

\section{BIBLIOGRAPHY}

Agard, John. Limbo Dancer in Dark Glasses. London: Greenheart, 1983.

Allsopp, Richard. Dictionary of Caribbean English Usage. Oxford: Oxford University Press, 1996.

Brathwaite, Edward Kamau. Islands. London: Oxford University Press, 1969.

Dawes, Kwame. Wheel and Come Again: An Anthology of Reggae Poetry. Leeds: Peepal Tree Press, 1998.

---. Natural Mysticism: Towards a New Reggae Aesthetic. Leeds: Peepal Tree Press, 1999.

Cuddon, J. H. Dictionary of Literary Terms and Literary Theory. London: Penguin, 1991.

Doumerc, Eric. "Versioning Caribbean Poems: An Interview with Geoffrey Philp." Jamaica Journal $35: 3$ (2015) : 73-77.

Escola, Marc. "Les relations transtextuelles selon G. Genette." 19 February 2003. 24 January 2016. <http://www.fabula.org/atelier.php?Les_relations_transtextuelles_selon_G._Genette>.

Genette, Gérard. Palimpsestes. Paris : Le Seuil, 1982.

Hebdige, Dick. Cut'n'Mix: Culture, Identity and Caribbean Music. London: Comedia, 1987.

Johnson, Linton Kwesi. Dread Beat and Blood. London: Bogle-L'Ouverture Publications Ltd, 1975.

Lodge, David. The Art of Fiction. London : Penguin, 1992.

Mordecai, Pamela (ed.). From Our Yard: Jamaican Poetry Since Independence. Kingston, Jamaica: Institute of Jamaica Publications, 1987.

Philp, Geoffrey. Florida Bound. Leeds: Peepal Tree Press, 1995.

---. Hurricane Center. Leeds: Peepal Tree Press, 1998.

---. Xango Music. Leeds: Peepal Tree Press, 2001.

---. Dub Wise. Leeds: Peepal Tree Press, 2010.

Pollard, Velma. Dread Talk: The Language of Rastafari. Kingston: Canoe Press, 1994.

Senior, Olive. Encyclopedia of Jamaican Heritage. St Andrews, Jamaica: Twin Guinep Publishers, 2003.

Walcott, Derek. The Fortunate Traveller. New York: Farrar, Straus and Giroux, 1981.

---. Midsummer. London: Faber and Faber, 1984.

---. Collected Poems: 1948-1984. London: Faber and Faber, 1986.

---. The Arkansas Testament. London: Faber and Faber, 1987. 


\section{NOTES}

1. During the 1930s a wave of riots and strikes swept through the English-speaking Caribbean, which led to the development of a new socially-conscious literature in Jamaica and other parts of the Caribbean.

2. "Idren" is a Rastafarian "I-word", that is a word whose first syllable has been replaced by "I" ("idren" = "brethren").

3. "Dawta" ("daughter") can refer to either "a female member of the Rastafarian cult" or "any young black woman, especially one sympathetic to the Rastafarian cult" (Allsopp 188).

4. "Bredren" = "brethren". A Rastafarian salutation or term of address.

5. Philp, who was born in 1958 in Jamaica, emigrated to Miami in 1979 and has been living there ever since.

\section{ABSTRACTS}

This article focuses on the influence of reggae on Geoffrey Philp's poetry through the concept of "versioning" ("creative recycling"), a cultural practice which goes back to the roots of reggae. This practice can be said to apply to the way Geoffrey Philp's poetry constitutes a kind of dialogue with Derek Walcott's poetry, with the classics of Jamaican poetry, and with reggae culture itself.

Cet article examine l'influence du reggae sur la poésie de Geoffrey Philp à travers le concept du "versioning" ("recyclage"), pratique qui remonte aux origines du reggae. Nous verrons comment cette pratique peut s'appliquer à la relation que la poésie de Geoffrey Philp entretient avec la poésie de Derek Walcott, les classiques de la poésie jamaïcaine, ainsi qu'avec la culture reggae à proprement parler.

\section{INDEX}

Mots-clés: esthétique, intertextualité, poésie, recyclage, reggae, versioning

Keywords: aesthetics, intertextuality, poetry, reggae, versioning

\section{AUTHORS}

\section{ERIC DOUMERC}

Maître de conférences

Université de Toulouse-Jean Jaurès

doumerceric@neuf.fr 